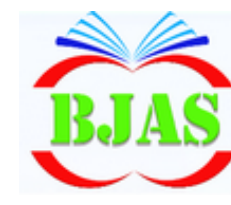

Available online at http://bajas.edu.iq https://doi.org/10.37077/25200860.2019.276 College of Agriculture, University of Basrah

ISSN $1814-5868$

Basrah J. Agric. Sci., 32(Spec. Issue 2): 283-291, 2019
Basrah Journal of Agricultural Sciences

\title{
N- Mineralization of Organic Residues in Flooded and Aerated Saline Soils under Different Temperature
}

\section{Rawan M. Hamid* \& Abd Al-Mehdi S. Al-Ansari}

Department of Soil Sciences and Water Resources, College of Agriculture, University of Basrah, Iraq

\author{
*Corresponding author e-mail: rawan.hamid94@gmail.com \\ Received 19 September 2019; Accepted 18 November 2019; Available online 22 November 2019
}

\begin{abstract}
Serious of incubation studies were conducted at Department of soil Science and Water Resources, College of Agriculture, university of Basrah to study the effect of temperature incubation and soil salinity levels $\left(3,6,12\right.$ and 24) dS.m ${ }^{-1}$ on $\mathrm{N}$ mineralization of cow manure and alfalfa residue under aerobic and flooded conditions. Fifteen gram of air dry soil with salinity levels of 3, 6, 12 and $24 \mathrm{dS} . \mathrm{m}^{-1}$ treated with 5\% of cow manure or alfalfa residue were incubated at 10,20 or $30{ }^{\circ} \mathrm{C}$ for 28 days. Moisture level of incubated soil was kept at either field capacity or flooded condition. $\mathrm{NH}_{4}{ }^{+}-\mathrm{N}$ and $\mathrm{NO}_{3}^{-} \mathrm{N}$ concentration of incubated samples were determined at the end of incubation period. Results showed that organic residues added to soils of all salinity levels increased $\mathrm{NH}_{4}{ }^{+}-\mathrm{N}$ and $\mathrm{NO}_{3}{ }^{-}-\mathrm{N}$. Concentrations of both ions were higher in alfalfa residue treatment than those of cow manure at all treatments. Highest concentrations of $\mathrm{NH}_{3}{ }^{+}-\mathrm{N}$ and $\mathrm{NO}_{3}{ }^{-}-\mathrm{N}$ ions in all treatments obtained at samples incubated at $30{ }^{\circ} \mathrm{C}$ and E.C. of $3 \mathrm{dS} . \mathrm{m}^{-1}$. Organic $\mathrm{N}$ mineralization under F.C. was higher than under logged water for all treatments.
\end{abstract}

Key words: $\mathrm{NH}_{4}{ }^{+}, \mathrm{NO}_{3}{ }^{-}$, Flooded, Field Capacity, Salinity, Temperature.

\section{Introduction}

Nitrogen is one of most important nutrient for plant growth. It involves in chlorophyll, proteins, enzymes, plant growth requires, among other (Leip et al., 2008). Plant absorbs $\mathrm{N}$ as $\mathrm{NH}_{4}{ }^{+}$and $\mathrm{NO}_{3}{ }^{-}$which usually supplied to plant by mineral and organic fertilizers. Organic fertilizers usually used by farmer as a supplementary for mineral $\mathrm{N}$ fertilizers (Ryals
\& Silver, 2013). Organic nitrogen fertilizers are represented by manures, plant residues and urea. The $\mathrm{N}$ component of manure and plant residues is mostly in protein form. The nitrogen as compounds in pretentious material undergo the following microbial decomposition:

$$
\begin{aligned}
& \text { Soil - organic }-\mathrm{N} \rightarrow \mathrm{R}-\mathrm{NH}_{2}+\mathrm{CO}_{2}+\text { other products + energy } \\
& \qquad \mathrm{R}-\mathrm{NH}_{2}+\mathrm{H}_{2} \mathrm{O} \rightarrow \mathrm{H}_{2} \mathrm{O} \downarrow \mathrm{NH}_{4} \mathrm{OH}+\mathrm{ROH}+\text { energy } \ldots \ldots . .
\end{aligned}
$$

Microbial decomposition of organic $\mathrm{N}$ in soil affected by properties of organic residues such as $\mathrm{C} / \mathrm{N}$ ratio, easily or non-easily decomposable organic molecules such as 
Hamid \& Al-Ansari/ Basrah J. Agric. Sci., 32(Spec. Issue 2): 283-291, 2019

lignin and other compounds_among other properties. In addition soil properties such as pH, CEC and E.C. (Sahrawat, 2010), temperature (Wetterstedt, 2010) and soil moisture show significant effect on organic $\mathrm{N}$ mineralization in soil. In addition Abbasi et al. (2015) pointed that $\mathrm{C} / \mathrm{N}$ of organic residue is a major factor affected the $\mathrm{N}$ mineralization process in soil. Soil moisture and salinity levels of irrigation water averages throughout the growing season, which in turn effect soil microorganism activity and biological process in soils. Hence, this study was carried to study the mineralization of cow manure and alfalfa residue under different moisture levels(F.C and logged water condition) and soil temperatures $\left(10,20\right.$ and $\left.30{ }^{\circ} \mathrm{C}\right)$ with different salinity levels $\left(3,6,12\right.$ and $\left.24 \mathrm{dS} \cdot \mathrm{m}^{-1}\right)$.

\section{Materials \& Methods}

Surface soil sample was collected from depth of 0-30 $\mathrm{cm}$ from a field located at Basrah province, southern part of Iraq. Some physical and chemical properties of the soil were determined following procedures described by Page et al. (1982) and presented in table (1). Initial electrical conductivity (E.C) of collected soil was raised to 3, 6, 12 and 24 $\mathrm{dS} . \mathrm{m}^{-1}$ through leaching with mixture of $\mathrm{NaCl}, \mathrm{CaSO}_{4}$ and $\mathrm{CaCl}_{2}$ or decreased to 3 $\mathrm{dS} . \mathrm{m}^{-1}$ through leaching with distilled water, then soil samples were air-dried. Some chemical properties of soil after adjusting of E.C were determined according to Page et al. (1982) and presented in table (1).

Table (1): Some chemical and physical and biological properties to soil.

\begin{tabular}{|c|c|c|c|c|c|c|}
\hline Property & Initial & \multicolumn{4}{|c|}{$\mathrm{EC}\left(\mathrm{dS} \cdot \mathrm{m}^{-1}\right)$} & Measure unit \\
\hline E.C. & 7.06 & 3 & 6 & 12 & 24 & $\mathrm{dS} . \mathrm{m}^{-1}$ \\
\hline $\mathrm{pH}$ & 7.94 & 7.97 & 7.95 & 7.92 & 7.89 & - \\
\hline CEC & 20.43 & 20.40 & 20.42 & 19.90 & 17.50 & $\mathrm{Cmol}^{(+)} \mathrm{kg}^{-1}$ \\
\hline Organic matter & 13.00 & - & - & - & - & \\
\hline Organic carbon & 7.55 & - & - & - & - & $\mathrm{gm} . \mathrm{kg}^{-1}$ \\
\hline Total nitrogen & 1.50 & - & - & - & - & \\
\hline $\mathrm{C}: \mathrm{N}$ & 5.03 & - & - & - & - & - \\
\hline $\mathrm{NH}_{4}-\mathrm{N}$ & 19.50 & 3.40 & 3.80 & 3.0 & 2.6 & \\
\hline $\mathrm{NO}_{2}-\mathrm{N}$ & 0.00 & 0.00 & 0.00 & 0.00 & 0.00 & $\mathrm{mg} . \mathrm{kg}^{-1}$ \\
\hline $\mathrm{NO}_{3}-\mathrm{N}$ & 2.90 & 0.17 & 0.15 & 0.14 & 0.10 & \\
\hline $\mathrm{CaCO}_{3}$ & 293.00 & 359.00 & 362.00 & 368.00 & 371.00 & gm. kg-1 \\
\hline $\mathrm{Ca}^{+2}$ & 16.00 & 8.00 & 14.00 & 24.00 & 45.00 & \\
\hline $\mathrm{Mg}^{+2}$ & 9.00 & 4.00 & 10.00 & 18.00 & 41.00 & \\
\hline $\mathrm{Na}^{+}$ & 17.00 & 5.00 & 10.00 & 22.00 & 43.00 & mmol. $\mathrm{L}^{-1}$ \\
\hline $\mathrm{K}^{+}$ & 3.00 & 1.50 & 3.00 & 9.00 & 18.00 & \\
\hline $\mathrm{CO}_{3}=$ & 0.00 & 0.00 & 0.00 & 0.00 & 0.00 & \\
\hline $\mathrm{HCO}_{3}^{-}$ & 7.00 & 4.00 & 7.00 & 15.00 & 30.00 & \\
\hline $\mathrm{Cl}^{-}$ & 16.00 & 5.00 & 12.00 & 28.00 & 56.00 & \\
\hline $\mathrm{SO}_{4}=$ & 22.00 & 10.00 & 20.00 & 36.00 & 72.00 & \\
\hline
\end{tabular}


Cow manure or alfalfa residue were mixed with soils at rate of $5 \%$ (organic source soil). Some chemical properties of organic source were determined according to Page et al. (1982) and presented in table (2). Fifteen grams (on dry soil bases) of the soils of different salinity levels treated with organic sources were placed in containers and incubated at three temperatures $(10,20$ and 30 $\left.{ }^{\circ} \mathrm{C}\right)$ for 28 days. The soil moisture of incubated samples was kept at either field capacity or logged water condition throughout incubation period. Desired moisture levels of incubated samples were maintained by periodic weighing of the containers.

Table (2): Some chemical properties to organic source.

\begin{tabular}{|c|c|c|}
\hline Property (Unite) & Alfalfa residue & Cow manure \\
\hline $\mathrm{pH}(5: 1)$ & 5.90 & 6.80 \\
\hline E.C $(5: 1)\left(\mathrm{dS} . \mathrm{m}^{-1}\right)$ & 6.89 & 7.10 \\
\hline Organic matter $\left(\mathrm{gm} . \mathrm{kg}^{-1}\right)$ & 655.66 & 635.02 \\
\hline Organic carbon $\left(\mathrm{gm} . \mathrm{kg}^{-1}\right)$ & 381.20 & 369.20 \\
\hline Total nitrogen gm. $\mathrm{kg}^{-1}$ & 46.50 & 29.20 \\
\hline Total phosphor $\left(\mathrm{gm} . \mathrm{kg}^{-1}\right)$ & 1.30 & 1.90 \\
\hline C:N Ratio & 8.20 & 12.64 \\
\hline
\end{tabular}

At the end of incubation period, samples were air-dried and mineralized $\mathrm{N}\left(\mathrm{NH}_{4}{ }^{+}-\mathrm{N}\right.$ and $\mathrm{NO}_{3}{ }^{-}+\mathrm{NO}_{2}{ }^{-}$) were determined by steam distillation following procedure of Bremner \& Edwards (1965). The study was carried as factorial experiment with three replicates in complete randomized design. Data were analyzed using GenStat program.

\section{Results \& Discussion}

$\mathrm{NH}_{4}{ }^{+}-\mathrm{N}$ released

Results of tables (3 and 4) showed that increasing incubation temperature from 10 to $30^{\circ} \mathrm{C}$ at all treatments resulted in significant increase in $\mathrm{NH}_{4}^{+}-\mathrm{N}$ released from both source of organic residue as well as from control treatmet at both moisture levels (F.C and logged water) and all salinity levels. Average of $\mathrm{NH}_{4}{ }^{+}-\mathrm{N}$ increased from 159.0 to $318.1 \mathrm{mg} \mathrm{kg}^{-1}$ soil in samples incubated under F.C (table 3) and from 227.0 to $451.56 \mathrm{mg} \mathrm{kg}^{-}$ 1 soil in samples incubated under logged water condition (table 4). Amount of $\mathrm{NH}_{4}{ }^{+}$$\mathrm{N}$ produced in soil samples incubated under different soil moisture were significantly differ being higher for soils incubated under logged water then F.C ( $\mathrm{t}$ value $=4.527)$.

Similar results were reported by PérezBatallón et al. (2001) and Cenkseven et al. (2017), who showed that increase soil temperature resulted in higher soil microorganisims activity, which in turn increase organic residue decomposition in soils. Data of tables (3 and 4) also revealed 
Hamid \& Al-Ansari/ Basrah J. Agric. Sci., 32(Spec. Issue 2): 283-291, 2019

that $\mathrm{NH}_{4}^{+}-\mathrm{N}$ concentration in soil treated with organic residues were higher than of control treatment at both moisture levels.

$\mathrm{NH}_{4}{ }^{+}$-N values were higher in soils amended with alfalfa residue (average 254.0 $\mathrm{mg} \cdot \mathrm{kg}^{-1}$ ) than their counterparts of soil treated with cow residue (average $250.4 \mathrm{mg} \cdot \mathrm{kg}^{-1}$ ).
However, lowest value was recorded at control treatment (196.9 $\left.\mathrm{mg} \cdot \mathrm{kg}^{-1}\right)$ in soil under F.C (table 3).

However, different trend for $\mathrm{NH}_{4}^{+}-\mathrm{N}$ concentration was recorded at soils incubated under logged water condition. Values of $\mathrm{NH}_{4}{ }^{+}$ -N concentration were $464.44 \mathrm{mg} \cdot \mathrm{kg}^{-1}$ as

Table (3): Effect of salinity levels and temperature on $\mathrm{NH}_{4}^{+}-\mathrm{N}$ mineralization in soil treated with cow manure or alfalfa residue incubated under F.C.

\begin{tabular}{|c|c|c|c|c|c|}
\hline \multirow[t]{2}{*}{ Source } & \multirow{2}{*}{$\begin{array}{c}\text { Salinity } \\
\text { levels } \\
\left(\mathrm{dS} . \mathrm{m}^{-1}\right)\end{array}$} & \multicolumn{3}{|c|}{ Temperature ${ }^{\circ} \mathrm{C}$} & \multirow{2}{*}{$\begin{array}{c}\text { Salinity } \\
\text { level } \times \\
\text { source }\end{array}$} \\
\hline & & 10 & 20 & 30 & \\
\hline \multirow[t]{4}{*}{ Control } & 3 & 168.0 & 205.3 & 308.0 & 227.1 \\
\hline & 6 & 158.7 & 177.3 & 289.3 & 208.4 \\
\hline & 12 & 149.3 & 168.0 & 226.0 & 181.1 \\
\hline & 24 & 121.3 & 140.0 & 251.3 & 170.9 \\
\hline \multirow[t]{4}{*}{ Cow manure } & 3 & 205.3 & 345.3 & 392.0 & 314.2 \\
\hline & 6 & 196.0 & 280.0 & 308.0 & 261.3 \\
\hline & 12 & 168.0 & 224.0 & 280.0 & 224.0 \\
\hline & 24 & 158.7 & 196.0 & 252.0 & 202.2 \\
\hline \multirow[t]{4}{*}{ Alfalfa } & 3 & 185.7 & 391.3 & 656.0 & 411.0 \\
\hline & 6 & 152.3 & 278.0 & 477.3 & 302.6 \\
\hline & 12 & 132.3 & 172.3 & 198.7 & 167.8 \\
\hline & 24 & 112.3 & 112.3 & 179.0 & 134.6 \\
\hline \multicolumn{2}{|c|}{ RLSD 0.05} & & 55.71 & & 233.7 \\
\hline \multicolumn{2}{|c|}{ Average effect temp. } & 159.0 & 224.2 & 318.1 & Average \\
\hline \multicolumn{2}{|c|}{ RLSD 0.05} & & 16.08 & & $\begin{array}{c}\text { type } \\
\text { source }\end{array}$ \\
\hline \multirow{3}{*}{$\begin{array}{l}\text { Type source } \times \\
\text { temp. }\end{array}$} & control & 149.3 & 172.7 & 268.7 & 196.9 \\
\hline & $\begin{array}{c}\text { Cow } \\
\text { manure }\end{array}$ & 182.0 & 261.3 & 308.0 & 250.4 \\
\hline & alfalfa & 145.7 & 238.5 & 377.8 & 254.0 \\
\hline \multicolumn{2}{|c|}{ RLSD 0.05} & & 27.85 & & 233.7 \\
\hline & & & & & $\begin{array}{c}\text { Average } \\
\text { of effect } \\
\text { salinity }\end{array}$ \\
\hline \multirow[t]{4}{*}{ Salinity $\times$ temp. } & 3 & 186.3 & 314.0 & 452.0 & 317.4 \\
\hline & 6 & 169.0 & 245.1 & 358.2 & 257.4 \\
\hline & 12 & 149.9 & 188.1 & 234.9 & 191.0 \\
\hline & 24 & 130.8 & 149.4 & 227.4 & 169.2 \\
\hline \multicolumn{2}{|c|}{ RLSD 0.05} & & 32.16 & & 233.7 \\
\hline
\end{tabular}


Hamid \& Al-Ansari/ Basrah J. Agric. Sci., 32(Spec. Issue 2): 283-291, 2019

average in soil amended with cow manure and $304.39 \mathrm{mg} \cdot \mathrm{kg}^{-1}$ as average in soil amended with alfalfa residue.

$\mathrm{NH}_{4}{ }^{+}-\mathrm{N}$ in control treatment recorded value of $192.11 \mathrm{mg} . \mathrm{kg}^{-1}$ soil (table 4). Result of Abbasi et al. (2015) showed that organic residue added to soil increased $\mathrm{NH}_{4}{ }^{+}-\mathrm{N}$ concentration.

Results of table (3) showed significant effect of organic sources on $\mathrm{NH}_{4}{ }^{+}-\mathrm{N}$ concentration in soil being higher for logged water level than under F.C level $(\mathrm{t}$ value $=$ 4.527). Increasing salinity levels from 3 to 24 $\mathrm{dS} . \mathrm{m}^{-1}$ decreased $\mathrm{NH}_{4}{ }^{+}-\mathrm{N}$ concentration from 317.4 to $169.2 \mathrm{mg} \cdot \mathrm{kg}^{-1}$ in soils of field capacity treatment (table 3 ) and from 401.78 to $264.56 \mathrm{mg} \cdot \mathrm{kg}^{-1}$ in soil incubation under logged water condition (table 4). These results are in accord with that of Inamura et al. (2009) and Walpola \& Arunakumara (2010), who showed that increasing

Table (4): Effect of salinity levels and temperature on $\mathrm{NH}_{4}^{+}-\mathrm{N}$ mineralization in soil treated with cow manure or alfalfa residue incubated under logged water.

\begin{tabular}{|c|c|c|c|c|c|}
\hline \multirow[t]{2}{*}{ source } & \multirow{2}{*}{$\begin{array}{c}\text { Salinity } \\
\text { levels } \\
\left(\mathrm{dS} . \mathrm{m}^{-1}\right)\end{array}$} & \multicolumn{3}{|c|}{ Temperature ${ }^{\circ} \mathrm{C}$} & \multirow{2}{*}{$\begin{array}{l}\text { Salinity level } \\
\times \text { source }\end{array}$} \\
\hline & & 10 & 20 & 30 & \\
\hline \multirow[t]{4}{*}{ control } & 3 & 175.0 & 182.0 & 420.0 & 259.0 \\
\hline & 6 & 147.0 & 161.0 & 294.0 & 200.67 \\
\hline & 12 & 126.0 & 147.0 & 208.67 & 160.56 \\
\hline & 24 & 105.0 & 140.0 & 199.67 & 148.22 \\
\hline \multirow[t]{4}{*}{ Cow manure } & 3 & 312.67 & 336.0 & 582.0 & 410.22 \\
\hline & 6 & 179.0 & 246.0 & 552.67 & 325.89 \\
\hline & 12 & 157.0 & 202.0 & 403.0 & 254.0 \\
\hline & 24 & 152.33 & 149.0 & 336.0 & 227.44 \\
\hline \multirow[t]{4}{*}{ alfalfa } & 3 & 459.0 & 515.0 & 634.33 & 536.11 \\
\hline & 6 & 332.33 & 440.67 & 616.0 & 463.00 \\
\hline & 12 & 298.67 & 418.33 & 605.0 & 440.67 \\
\hline & 24 & 280.0 & 406.67 & 567.33 & 418.0 \\
\hline \multicolumn{2}{|c|}{ RLSD 0.05} & & 16.826 & & 320.31 \\
\hline \multicolumn{2}{|c|}{ Average effect temp. } & 227.0 & 282.39 & 451.56 & type Average \\
\hline \multicolumn{2}{|c|}{ RLSD 0.05} & & 4.857 & & source \\
\hline \multirow{3}{*}{$\begin{array}{l}\text { Type source } \times \\
\text { temp. }\end{array}$} & Control & 138.25 & 157.5 & 280.58 & 192.11 \\
\hline & $\begin{array}{l}\text { Cow } \\
\text { manure }\end{array}$ & 200.25 & 244.50 & 468.42 & 304.39 \\
\hline & Alfalfa & 342.5 & 445.17 & 605.67 & 464.44 \\
\hline \multicolumn{2}{|c|}{ RLSD 0.05} & & 4.857 & & 320.31 \\
\hline & & & & & $\begin{array}{c}\text { Average of } \\
\text { effect salinity }\end{array}$ \\
\hline \multirow[t]{4}{*}{ Salinity $\times$ temp } & 3 & 315.56 & 344.33 & 545.44 & 401.78 \\
\hline & 6 & 219.44 & 282.56 & 487.56 & 329.85 \\
\hline & 12 & 193.89 & 255.78 & 405.56 & 285.07 \\
\hline & 24 & 179.11 & 246.89 & 367.67 & 264.56 \\
\hline \multicolumn{2}{|c|}{ RLSD 0.05} & & 5.609 & & 320.31 \\
\hline
\end{tabular}


Hamid \& Al-Ansari/ Basrah J. Agric. Sci., 32(Spec. Issue 2): 283-291, 2019

salinity level decreased microbial activity in soil. Therefore, organic residue decomposing in soil is decreased.

On other hand, Khalil et al. (2005) indicated that increasing soil salinity level to about $6.0 \mathrm{dS} . \mathrm{m}^{-1}$ showed no significant effect on $\mathrm{NH}_{4}{ }^{+}-\mathrm{N}$ concentration in soil. Al-Jaberi (2010) indicated that effect of salinity on soil microbial activity and depends on the initial soil salinity level. Data of tables (3 and 4) showed that highest value of $\mathrm{NH}_{4}^{+}-\mathrm{N}$ produced in soil was obtained at soil amended with alfalfa residue incubated at $30 \mathrm{C}^{\circ}$ and salinity level of $3 \mathrm{dS} . \mathrm{m}^{-1}$ and recorded values $656.0 \mathrm{mg} . \mathrm{kg}^{-1}$ and $634.33 \mathrm{mg} . \mathrm{kg}^{-1}$ for F.C and logged water conditions, respectively. Significant effect for the interaction between salinity level and source of organic residues, organic residue and temperature of incubation, temperature and salinity were recorded (tables $3 \& 4$ ). Results of tables (5 and 6) showed that increasing incubation temperature from 10 to $30{ }^{\circ} \mathrm{C}$ at all treatment increased $\mathrm{NO}_{3}{ }^{-}-\mathrm{N}$ concentration in soil.

Table (5): Effect of salinity levels and temperature on $\mathrm{NO}_{3}{ }^{-}-\mathrm{N}$ mineralization in soil treated with cow manure or alfalfa residue incubated under F.C.

\begin{tabular}{|c|c|c|c|c|c|}
\hline \multirow[t]{2}{*}{ source } & \multirow{2}{*}{$\begin{array}{l}\text { Salinity levels } \\
\left(\mathrm{dS} . \mathrm{m}^{-1}\right)\end{array}$} & \multicolumn{3}{|c|}{ Temperature ${ }^{\circ} \mathrm{C}$} & \multirow{2}{*}{$\begin{array}{c}\text { Salinity level } \\
\times \text { source }\end{array}$} \\
\hline & & 10 & 20 & 30 & \\
\hline \multirow{4}{*}{ control } & 3 & 196.0 & 252.0 & 616.0 & 354.7 \\
\hline & 6 & 196.0 & 233.3 & 373.3 & 267.6 \\
\hline & 12 & 177.3 & 186.7 & 364.0 & 242.7 \\
\hline & 24 & 149.3 & 158.7 & 326.7 & 211.6 \\
\hline \multirow[t]{4}{*}{ Cow manure } & 3 & 205.3 & 382.7 & 644.0 & 410.7 \\
\hline & 6 & 196.0 & 308.0 & 625.3 & 376.4 \\
\hline & 12 & 185.3 & 233.3 & 448.0 & 288.9 \\
\hline & 24 & 168.0 & 177.3 & 420.0 & 255.1 \\
\hline \multirow{4}{*}{ alfalfa } & 3 & 666.3 & 697.7 & 876.0 & 746.7 \\
\hline & 6 & 564.7 & 634.7 & 787.3 & 662.2 \\
\hline & 12 & 425.3 & 609.0 & 704.3 & 579.6 \\
\hline & 24 & 280.0 & 469.7 & 666.0 & 471.9 \\
\hline \multicolumn{2}{|c|}{ RLSD 0.05} & \multicolumn{3}{|c|}{130.14} & 405.7 \\
\hline \multicolumn{2}{|c|}{ Average effect temp. } & 284.1 & 361.9 & 570.9 & \multirow{2}{*}{$\begin{array}{c}\text { Average type } \\
\text { source }\end{array}$} \\
\hline \multicolumn{2}{|c|}{ RLSD 0.05} & \multicolumn{3}{|c|}{37.57} & \\
\hline \multirow{3}{*}{$\begin{array}{l}\text { Type source } \\
\times \text { temp. }\end{array}$} & Control & 179.7 & 207.7 & 420 & 269.1 \\
\hline & Cow manure & 188.7 & 275.3 & 534.3 & 332.8 \\
\hline & Alfalfa & 484.1 & 602.8 & 758.4 & 615.1 \\
\hline \multicolumn{2}{|c|}{ RLSD 0.05} & \multicolumn{3}{|c|}{37.57} & 405.7 \\
\hline & & & & & $\begin{array}{l}\text { Average of } \\
\text { effect salinity }\end{array}$ \\
\hline \multirow{4}{*}{$\begin{array}{l}\text { Salinity } \times \\
\text { temp. }\end{array}$} & 3 & 355.9 & 444.1 & 712.0 & 504.0 \\
\hline & 6 & 318.9 & 392.0 & 595.3 & 435.4 \\
\hline & 12 & 262.7 & 343.0 & 505.4 & 370.4 \\
\hline & 24 & 199.1 & 268.6 & 470.9 & 312.9 \\
\hline \multicolumn{2}{|c|}{ RLSD 0.05} & \multicolumn{3}{|c|}{43.38} & 405.7 \\
\hline
\end{tabular}


Hamid \& Al-Ansari/ Basrah J. Agric. Sci., 32(Spec. Issue 2): 283-291, 2019

\section{$\mathrm{NO}_{3}{ }^{-} \mathrm{N}$ Concentration}

Average values of $\mathrm{NO}_{3}{ }^{-}-\mathrm{N}$ increased from 284.1 to $570.9 \mathrm{mg} \cdot \mathrm{kg}^{-1}$ in soil incubated under F.C moisture level and from 104.97 to 184.19 mg.kg ${ }^{-1}$ for soil incubated under logged water level. Similar effect of temperature on $\mathrm{NO}_{3}{ }^{-} \mathrm{N}$ concentration in soil was reported by Yeasmin et al. (2012) and Cenkseven et al. (2017). Data of treated tables (5 \& 6) clearly indicated that $\mathrm{NO}_{3}{ }^{-}-\mathrm{N}$ concentration in soil treatment with organic residues were higher than of control treatment at both moisture levels and all temperatures of incubation. Average values of $\mathrm{NO}_{3}{ }^{-}-\mathrm{N}$ increased from 269.1 at control treatment to $332.8 \mathrm{mg} \cdot \mathrm{kg}^{-1}$ in soil amended with cow manure and 615.1. $\mathrm{mg} \cdot \mathrm{kg}^{-1}$ in soil treated with alfalfa residue in soil incubated under F.C condition. However, values of $\mathrm{NO}_{3}^{-}-\mathrm{N}$ in soil incubated under logged water condition were $109.5 \mathrm{mg} . \mathrm{kg}^{-1}$, $186.25 \mathrm{mg} . \mathrm{kg}^{-1}, 118.92 \mathrm{mg} . \mathrm{kg}^{-1}$ for control, cow manure and alfalfa residue, respectively.

Table (6): Effect of salinity levels and temperature on $\mathrm{NO}_{3}^{-}-\mathrm{N}$ mineralization in soil treated with cow manure or alfalfa residue incubated under logged water.

\begin{tabular}{|c|c|c|c|c|c|}
\hline \multirow[t]{2}{*}{ source } & \multirow{2}{*}{$\begin{array}{l}\text { Salinity levels } \\
\left(\mathrm{dS} . \mathrm{m}^{-1}\right)\end{array}$} & \multicolumn{3}{|c|}{ Temperature ${ }^{\circ} \mathrm{C}$} & \multirow{2}{*}{$\begin{array}{c}\text { Salinity level } \times \\
\text { source }\end{array}$} \\
\hline & & 10 & 20 & 30 & \\
\hline \multirow[t]{4}{*}{ control } & 3 & 99.0 & 111.0 & 209.33 & 139.78 \\
\hline & 6 & 85.0 & 104.67 & 154.0 & 114.56 \\
\hline & 12 & 74.0 & 92.0 & 129.0 & 98.33 \\
\hline & 24 & 59.0 & 80.33 & 116.67 & 85.33 \\
\hline \multirow[t]{4}{*}{ Cow manure } & 3 & 168.0 & 188.0 & 336.0 & 230.67 \\
\hline & 6 & 140.0 & 168.0 & 242.67 & 183.56 \\
\hline & 12 & 130.0 & 185.67 & 224.0 & 170.89 \\
\hline & 24 & 115.67 & 149.33 & 214.67 & 159.89 \\
\hline \multirow[t]{4}{*}{ alfalfa } & 3 & 116.0 & 131.0 & 176.0 & 141.0 \\
\hline & 6 & 106.0 & 116.0 & 146.0 & 122.67 \\
\hline & 12 & 91.0 & 106.0 & 141.0 & 112.67 \\
\hline & 24 & 76.0 & 101.0 & 121.0 & 99.33 \\
\hline \multicolumn{2}{|c|}{ RLSD 0.05} & & 14.631 & & 138.22 \\
\hline \multicolumn{2}{|c|}{ Average effect temp. } & 104.97 & 125.5 & 184.19 & Average type \\
\hline \multicolumn{2}{|c|}{ RLSD 0.05} & & 4.224 & & source \\
\hline \multirow{3}{*}{$\begin{array}{c}\text { Type source } \\
\text { temp. }\end{array}$} & control & 79.25 & 97.0 & 152.25 & 109.50 \\
\hline & $\begin{array}{c}\text { Cow } \\
\text { manure }\end{array}$ & 138.42 & 166.0 & 254.33 & 186.25 \\
\hline & alfalfa & 97.25 & 113.5 & 146.0 & 118.92 \\
\hline \multicolumn{2}{|c|}{ RLSD 0.05} & & 4.224 & & 138.22 \\
\hline & & & & & $\begin{array}{c}\text { Average of } \\
\text { effect salinity }\end{array}$ \\
\hline \multirow{4}{*}{$\begin{array}{l}\text { Salinity } \times \\
\text { temp. }\end{array}$} & 3 & 127.67 & 143.33 & 240.44 & 170.48 \\
\hline & 6 & 110.33 & 129.56 & 180.89 & 140.26 \\
\hline & 12 & 98.33 & 118.89 & 164.67 & 127.30 \\
\hline & 24 & 83.56 & 110.22 & 150.78 & 114.85 \\
\hline \multicolumn{2}{|c|}{ RLSD 0.05} & & 4.877 & & 138.22 \\
\hline
\end{tabular}


These results are in agreement with that of Balkcom et al. (2009) and Anggria et al. (2012) and who showed that concentration of $\mathrm{NO}_{3}{ }^{-} \mathrm{N}$ in soil differs according to types and amount of organic residue added to soils. Results showed a significant differences in $\mathrm{NO}_{3}{ }^{-}-\mathrm{N}$ produce from different organic source at all moisture treatments of incubated soils, being higher in soils incubated under F.C than logged water condition ( $\mathrm{t}$ value $=12.073)$.

Increasing salinity level from 3 to 24 Ds.m ${ }^{1}$ decreased $\mathrm{NO}_{3}{ }^{-}-\mathrm{N}$ concentration from 504.0 to $312.9 \mathrm{mg} . \mathrm{kg}^{-1}$ in soils incubated under F.C moisture level (table 5) and from 170.48 to $114.85 \mathrm{mg} . \mathrm{kg}^{-1}$ in soil incubated under logged water condition. Sahrawat (2009) stated that rate of organic residue decomposing in soil decreased as soil salinity level increased. Highest values $\left(876.0 \mathrm{mg} \cdot \mathrm{kg}^{-1}\right.$ ) for $\mathrm{NO}_{3}{ }^{-}-\mathrm{N}$ in soil incubated under F.C was obtained in soil with E.C $3 \mathrm{dS} . \mathrm{m}^{-1}$ treated with alfalfa residue and incubated at $30{ }^{\circ} \mathrm{C}$, while lowest value $149.3 \mathrm{mg} \cdot \mathrm{kg}^{-1}$ was record in control soil with E.C $24 \mathrm{dS} . \mathrm{m}^{-1}$ incubated at $10^{\circ} \mathrm{C}$ in soils incubated under F.C condition. However, in soil amended with cow residue highest values were record in soil with E.C $3 \mathrm{dS} . \mathrm{m}^{-1}$ and incubated at $30^{\circ} \mathrm{C}$, while lowest value was obtained in control soil with E.C $24 \mathrm{dS} . \mathrm{m}^{-1}$ incubated at $10^{\circ} \mathrm{C}$, these values were 336.0 mg. $\mathrm{kg}^{-1}$ and $59.0 \mathrm{mg} . \mathrm{kg}^{-1}$, respectively. Significant interaction between soil salinity levels and organic residue source and soil salinity level and temperature of incubation and temperature and organic source were recorded (tables 5 and 6).

\section{Conclusions}

It could be concluded from the data presented that organic residue source and soil salinity level have significant effect on organic $\mathrm{N}$ mineralization in soils under both F.C and logged water condition. Effect of soil logged water on organic $\mathrm{N}$ mineralization differs according to type of organic residue source.

\section{Acknowledgment}

We would like to thank the Department of soil sciences and water resources, College of Agriculture, University of Basrah for providing space and resources and scientific for this research.

\section{References}

Abbasi, K.M.; Mahmood, M.; Tahir, N.; Sabir, \& Khurshid, M. (2015). Impact of the addition of different plant residues on nitrogen mineralization-immobilization turnover and carbon content of a soil incubation under laboratory conditions. Solid Earth, 6: 197-205.

Anggria, L.; Kasno, A. \& Rochayati, S. (2012). Effect of organic matter on nitrogen mineralization in flooded and dry soil. J. Agric. Biol. Sci., 7(8): 586.

Al-Jaberi, M.M. (2010). Amidohydrolases activity,kinetic and thermodynamic parameters in some marsh and southern Iraqi soils. Ph. D. Coll. Agric., Univ. Basrah: 220pp. (In Arabic).

Balkcom, K.S., Blackmer, A.M. \& Hansen, D.J. (2009). Measuring soil nitrogen mineralization under field conditions. Commun. Soil Sci. Plan Anal., 40: 10731086.

Bremner, J.M. \& Edwards, A.P. (1965). Determination and Isotope ratio analysis of different forms of nitrogen in soil : I. Apparatus and procedure for distillation and determination of ammonium. Soil Sci. Soc. Amer. Proc., 29: 504-507.

Cenkseven, S.; Kizildag, N.; Kocak, B.; Sagliker, H. \& Darici, C. (2017). Soil organic matter mineralization under 
Hamid \& Al-Ansari/ Basrah J. Agric. Sci., 32(Spec. Issue 2): 283-291, 2019

different temperatures and moisture conditions in Kizıldağ Plateau, Turkey. Sains Malays., 46(5): 763-771.

Inamura, T.; Mukai, Y.; Maruyama, A.; Ikenage, S.; Uili Li, G.; Bu, X.; Xiang, Y.; Qin, D. \& Takahisa,. A.(2009). Effect of nitrogen mineralization on paddy rice yield under low input conditions in irrigated rice-based multiple cropping with intensive cropping of vegetables in Southwest China. Plant Soil, 315: 195209.

Khalil, M.I.; Hossain, M.B. \& Schmidhalter, U. (2005). Carbon and nitrogen mineralization in different upland soils of the subtropics treated with organic material. Soil Biol. Biochem., 37: 15071518.

Leip, A.; Marchi, G.; Koeble, R.; Kempen, M.; Britz, W. \& Li, C. (2008). Linking an economic model for Europe agriculture with a mechanistic model to estimate nitrogen and carbon losses from arable soils in Europe. Biogeosciences, 5: 73-94.

Page, A.L.; Miller, R.H. \& Keeney, D.R. (1982). Method of Soil Analysis. Part 2. $2^{\text {nd }}$ ed. ASA. Inc. Madison, Wisconsin, 1158pp.

Pérez-Batallón, P.; Oruo, G.; Macais, F. \& Merino, A. (2001). Initial mineralization of organic matter in a forest plantation soil following different logging residue management techniques. Ann. For. Sci., 58: 807-818.

Ryals, R. \& Silver, W.L. (2013). Effects of organic matter amendments on net primary productivity and greenhouse gas emissions in annual grasslands. Ecol. Appl., 23: 46-52

Sahrawat, K.L. (2009). Factors affecting nitrification in soils. Commun. Soil Sci. Plan Anal, 39: 1436-1446.

Sahrawat, K.L. (2010). Nitrogen mineralization in lowland rice soils: The role of organic matter quantity and quality. Arch. Agron. Soil Sci., 56(3): 337-353.

Yeasmin, S.; Mominul Islam, A.K.M. \& Aminul Islam, A.K.M. (2012). Nitrogen fractionation and its mineralization in paddy soils: A review. J. Agric. Technol., 8(3): 775-793.

Walpola, B.C. \& Arunakumara K.K.I.U. (2010). Effect of salt stress on decomposition of organic matter and nitrogen mineralization in animal manure amended soils. J. Agric. Sci., 5(1): 9-18.

Wetterstedt, M. (2010). Decomposition of Soil Organic Matter: Experimental and modelling studies of the importance of temperature and quality $\mathrm{Ph}$. D. Thesis. Acta Universitatis Agriculturae Sueciae: 36pp. 